\title{
CRIMINAL RESPONSIBILITIES ADOLESCENTS AND FEATURES OF PUNISHMENT SYSTEM
}

\author{
CPalvanov I., Tashkent State University of Law, Tashkent, Uzbekistan, palvanov.izzat@mail.ru
}

\section{УГОЛОВНАЯ ОТВЕТСТВЕННОСТЬ НЕСОВЕРШЕННОЛЕТНИХ И ОСОБЕННОСТИ ПЕНИТЕНЦИАРНОЙ СИСТЕМЫ}

\section{СПалванов И. Т., Ташкентский государственный юридический университет, \\ 2. Ташкент, Узбекистан, palvanov.izzat@mail.ru}

Abstract. This article provides information on juvenile justice and correctional work, restriction of liberty, and mandatory community service. There are general social measures for the prevention of adolescent's delinquency, special criminological measures for the prevention of conditionally convicted adolescents, as well as special preventive measures for this category of minors.

Аннотащия. В данной статье дается информация об уголовном наказании несовершеннолетних и исправительных работах, ограничениях свободы и назначении принудительного труда. Существуют общие социальные меры по предупреждению преступности среди несовершеннолетних, специальные криминологические меры по предупреждению условно осужденных несовершеннолетних, a также специальные профилактические меры для этой категории несовершеннолетних.

Keywords: adolescents convicts, correctional work, restraint of liberty, forced labor, crime prevention, sentencing, general social prevention, special criminological measures, individual preventive measures.

Ключевые слова: несовершеннолетние осужденные, исправительные работы, ограничение свободы, назначение принудительного труда, предупреждение преступности, вынесение приговоров, общая социальная профилактика, специальные криминологические меры, индивидуальные профилактические меры.

In the Republic of Uzbekistan, along with measures to educate fully developed minors, ensure their social protection and stimulate talented youth, work is underway to correct and acquire juvenile delinquents.

As a result, about 75 per cent of serious and very serious crimes were classified as less serious and less serious crimes. As a result, articles of the Criminal Code of the Republic of Uzbekistan, providing for serious and very serious crimes, were significantly reduced. Currently, the fight against juvenile delinquency is one of the priorities of the judicial system.

Currently, the criminal policy of the state is aimed at bringing criminal and criminal law in line with the principles of humanity, the rule of law and the priority of respect for the rights and legitimate interests of the individual. Success in this area is impossible without observing and monitoring the above principles of state criminal law in the field of juvenile delinquency.

Today, the main problem in this area can be distinguished by two opposite trends: on the one hand, the legislator is trying to bring all legal documents in line with international standards that 
minimize the criminal liability for minors, on the other hand, the criminal liability of minors, the crime rate among minors and the severity of their crimes. The development of optimal responses to both trends in juvenile delinquency is one of the priorities of criminal policy.

One of such measures may be the use of juvenile delinquency in the form of restrictions on freedom. Foreign criminal laws contain criminal penalties, such as parole, which are essentially limited to those who are punished - minors, women, and others who are punished by the seriousness of the punishment component and the specifics of this category [1, p. 18-20]. The uniformity of a foreign testing institution and the use of restrictions for adolescents are the most effective means of influencing juvenile offenders and are also included in the system of measures to prevent juvenile delinquency. A similar assumption, even if the sentence has already been passed, is that the restriction of liberty was intended to correct the convicted person, and then the prisoner. In its present form, it is a state coercive measure, which in many cases understands the purpose of preventive measures in nature $[2$, p. 58].

This specific goal of juvenile criminal punishment is a priority. This is because an adolescent by age is not formed either physiologically or psychologically, so we cannot talk about correction.

The fact that the liberalization of criminal sentences has reduced the number of prisoners in recent years has doubled, which also indicates that reforms in this area have yielded positive results. The Decree of the President No. 4850 of the Republic of Uzbekistan "On measures to further reform the judicial system, strengthening the guaranteed protection of the rights and freedoms of citizens" [3] points to a new stage of reform in this area.

A comprehensive program of measures, developed as a supplement to this Decree, also provides for the liberalization of criminal penalties for minors.

Also, Presidential Decree No. 3723 of the Republic of Uzbekistan "On measures to radically improve the criminal and criminal procedural legislation" [4], as a consistent continuation of the reform, is called upon to develop a new version of the Criminal Procedure Code of the Republic of Uzbekistan.

Section VI of the Criminal Code of the Republic of Uzbekistan "Features of the responsibility of minors" establishes the punishments that may be imposed on minors, as well as the maximum number, terms, conditions of release from punishment. Article 81 of the Code contains a list of criminal penalties, including fines, community service, correctional labour, restriction of liberty and imprisonment. According to articles 50 and 51 of the Criminal Code, minors cannot be sentenced to long or life imprisonment [5].

Punishments for minors differ from other types of criminal punishments that are not related to the complete separation of a person from society. Section 83 of the Criminal Code stipulates that correctional labor shall be assigned to minors from only one month to one year in their workplace, with the exception of the place of residence determined by the penitentiary authorities.

Thus, it is assumed that the essence of punishment is the essence of punishment, significantly reduced in terms of limiting the rights of prisoners. However, the restriction of freedom in the system of punishments imposed on minors is established in article 841 of the Criminal Code. In this regard, this article, in our opinion, should be formulated as follows: these are the types of punishments imposed by minors. Article 81 of the Criminal Code of the Republic of Uzbekistan provides the following basic penalties for persons who have committed crimes under the age of eighteen:

- fry;

- compulsory community service $1[6]$;

- correctional work;

- restriction of freedom1 [7]; 


\section{- imprisonment.}

Persons who have committed crimes under the age of eighteen years may not be subjected to additional punishments.

Experts argue that social attitudes related to juvenile delinquency and the state's attitude towards them do not provide a sufficiently separate approach to minors [8, p. 182].

This is especially true in relation to the Criminal and Criminal Code, which sets out the specifics of the application of coercive measures against minors, as well as the conditions and conditions of their stay in special educational institutions, the educational process and educational effects [9], but the specifics of the execution of sentences is not related to separation prisoners from society and the application of other criminal law measures.

According to article 85 of the Criminal Code, juveniles can be punished, compulsory community service, corrective measures, restriction of liberty, with the exception of the period of imprisonment. Measures to combat juvenile delinquency, other specific measures established by law, and measures to combat juvenile delinquency allow courts to make various decisions.

An analysis of the activities of the courts in recent years shows a slow but steady trend towards a decrease in the proportion of imprisonment and the use of other forms of punishment and criminal sanctions against minors.

Thus, large-scale measures are being taken against minors. Although various bodies are criminal in nature, the legal regulation of this activity is governed by general rules that can affect the effectiveness of criminal executive law - correction of prisoners and prevention of their new crimes.

At the same time, a feature of juvenile correctional labor is the reduction of the sentence to one year. The Supreme Court has clarified some issues that arise in the sentencing of a minor. Firstly, the courts were instructed that corrective measures could be applied to minors, which could be corrected through social use. Secondly, the impact of the sentence on the upbringing of the minor and his or her behavior in everyday life and in the family should be clarified. Thirdly, the court recommended making corrections to minors who are daily trained in educational institutions.

The Supreme Court demanded that the courts register different age groups, that minors under the age of fourteen have a general education and work under employment contracts with the consent of one of the parents and guardianship. Convicted minors under the age of fifteen are appointed to those who have or received a general education or work under an employment contract. For these reasons, the courts do not recommend the correction of juvenile offenders.

The peculiarity of forced labor of minors is that the law imposes restrictions on the punishment of adults. For minors of working age, this period is from 60 to 240 hours. Duration of execution is 6 months for people aged 16 to 18 years and 2 hours a day for up to 1 year, regardless of conviction [10]. At the same time, the work they perform should not harm their health and spiritual development, and should not interfere with the learning process. Judicial practice is aware of sentences that include criminal sentences, the terms of which exceed the limits established by the Criminal Code.

Daily time restrictions for attracting minors: the period of compulsory public work days should not exceed 3 hours for minors who do not study or do basic work. Working days and days of training should not exceed 2 hours before or after work / study, and at the request of the convict - 2 hours 3 days a week for minors [10]. When executing sentences, it is necessary to take into account the involvement of juvenile delinquents in work and juvenile delinquents in community service.

The restriction of freedom for minors is at the upper limit of his appointment and the execution period is two years. In addition, the restriction on the release of minors can only be used as a serious punishment. 
Thus, it is obvious that in the current form, persons under the age of eighteen may be subject to restrictions on freedom. Legal information on the legal actions of those who do this may indicate that the most relevant issues are those that are most likely to be affected by this type of situation. Currently, the tyranny of the faithful managed to get imprisonment on the list of victims of the massacre.

In addition, it should be noted that although the number of juvenile offenders has not officially changed, such an expansion is still taking place. This is due to the fact that in the juvenile justice system, imprisonment in the form of a restriction can not be applied so far.

The prevalence of crime among young people can be perceived as a predictor of crime for no reason. It is no coincidence that the prevention of juvenile delinquency is seen throughout the world as an important area of crime prevention in society as a whole.

Repeated juvenile crime is considered an extremely negative criminological phenomenon. Repeated (periodic) crimes in some cases indicate the formation of constant ill-treatment of such minors. Many of these minors become dangerous and professional criminals and even "thieves of the law".

Juvenile delinquency is a particularly disturbing probationary period. Conditional conviction is the most common remedy used by minors in court. Together, the suspended sentence provides a high level of crime, which suggests that the preventive measures applied to juvenile convicts are ineffective and, of course, need to be improved. In addition, some suspended minors leave the courtroom after being sentenced and commit various crimes on their way home.

The root causes and circumstances of their offenses must be examined to prevent juvenile delinquency.

After conditional conviction, the factors that determine the underlying crime are not only eliminated, but the illegal treatment of prisoners on parole is often exacerbated. To prevent successful juvenile delinquency, general measures of social prevention should be applied, the basic principles of which should be discussed in detail, as well as assistance to parents in fulfilling their educational functions, as well as the provision of pedagogical and methodological assistance in correcting the education of conditionally convicted children.

Free, useful and conditionally sentenced minors for positive changes (free sports sections, creative, technical and other circles and centers of interest, which can be one of the main functions of free time for minors).

It is necessary to prepare and implement at the state level the prevention of drug addiction and drug addiction among young people, including those who are in probation. To develop measures to increase the effectiveness of the preventive work of institutions and institutions involved in the prevention of juvenile delinquency.

In addition to restoring the well-being of probation minors, it is especially important to build a responsible attitude to their past, present and future behavior. To ensure the effective functioning of juvenile courts, it is necessary to establish investigative bodies for minors, juvenile prosecutors, lawyers and juvenile justice bodies. In this case, regulation is required for training specialists in these bodies with knowledge of juvenile law, adolescent psychology, pedagogy and methods of dealing with juvenile offenders. Juvenile justice systems should include institutions and institutions that have been violated in the interests of minors.

The joint work of such specialists, in our opinion, will more effectively prevent juvenile testing, which will positively affect the criminal situation as a whole.

In some regions, the establishment of social rehabilitation centers has a positive impact on the situation with juvenile delinquency, which provides for a comprehensive socio-psychological rehabilitation of minors and their parents, where they prepare for normal family relationships. 
Unfortunately, a certain number of juvenile offenders commit repeated crimes and then serve their sentences in prison, where special guarantees apply to these categories. Special criminological and individual activities in correctional facilities are closely intertwined [11, p. 130-134].

At the end of the article, it is considered appropriate:

- The crime of conditionally convicted juveniles is an independent object of research, and its prevention is very important, since in this category of people there is a high proportion of relapses.

- The main causes of juvenile delinquency are: their social disadvantages, as well as serious shortcomings in the organization of preventive work (distribution of preventive measures, a formal approach to preventive care, the use of individual methods of treatment of juvenile prisoners).

- Testing of minors in order to improve the crime prevention system should be carried out comprehensively, and general social, special criminological and individual measures should be taken to prevent this category of people.

The foregoing demonstrates confidence in juvenile delinquency and the particularities of the penitentiary system, as well as the ability to punish juvenile offenders in the prevention of offenses. In this regard, the society itself should be influenced by the upbringing of the younger generation, respect for moral values, laws and social norms, the development of self-esteem, the ability to respect their rights and freedoms, as well as civic duty.

The role of the state in improving the living standards of the population in this process is objective. Only with these components can other minors understand the exact punishment of offenders and take the necessary preventive measures.

A common link between the goals of punishment is the fight against crime. Responsibility for them is carried out objectively, which contributes to an increase in the sense of responsibility both among individual citizens and among other citizens.

Thus, it should be noted that all the goals of the juvenile justice system, although they have their own characteristics and mechanisms of their own success, are closely interconnected. Proper consideration of the unity of their relationship will help you better understand the nature and nature of the punishment of minors and determine how to influence them.

\section{References:}

1. Dolgopolov, K. A. (2016). Features of Assignment of Punishment to Minors in Some Countries of the Western Europe. Mezhdunarodnoe ugolovnoe pravo i mezhdunarodnaya yustitsiya, (3), 17-20. (in Russian).

2. Razogreeva, A. M., \& Min'kov, M. M. (2010). Probation and Restraint: Supervision or/and Re-Socialization. Ugolovnoe pravo, (4), 47-51. (in Russian).

3. Ukaz Prezidenta Respubliki Uzbekistan «O merakh po dal'neishemu reformirovaniyu sudebno-pravovoi sistemy, usileniyu garantii nadezhnoi zashchity prav i svobod grazhdan» 21.10.2016 UP-4850 http://lex.uz

4. Postanovlenie Prezidenta Respubliki Uzbekistan «O merakh po kardinal'nomu sovershenstvovaniyu sistemy ugolovnogo i ugolovno-protsessual'nogo zakonodatel'stva» 14.05.2018 PP-3723 [http://lex.uz

5. Ugolovnyi kodeks Respubliki Uzbekistan. http://lex.uz

6. Stat'ya 81 dopolnena punktom «a1» Zakona Respubliki Uzbekistan ot 29 marta 2017 goda № 421. Sobranie zakonov Respubliki Uzbekistan. № 13. st.194, 2017.

7. Zakon Respubliki Uzbekistan ot 10 avgusta 2015 goda «O vnesenii izmenenii i dopolnenii v nekotorye zakonodatel'nye akty Respubliki Uzbekistan» // Sobranie zakonodatel'stva Respubliki Uzbekistan. 2015. №32. 
8. Popov, V. V. (2012). Problemy formirovaniya i realizatsii ugolovnoi i ugolovnoispolnitel'noi politiki v otnoshenii nesovershennoletnikh. Vologda. (in Russian).

9. Ugolovno-ispol'nitel'nyi Kodeks Respubliki Uzbekistan http://lex.uz

10. Informatsionno-pravovoi portal. https://www.norma.uz

11. Feizullaev, F. M. (2015). Special Measures of Preventing Juvenile Delinquency in a Penitentiary. Chelovek: prestuplenie i nakazanie, (2 (89)). 130-134. (in Russian).

\section{Список литературы:}

1. Долгополов К. А. Особенности назначения наказания несовершеннолетним в некоторых странах Западной Европы // Международное уголовное право и международная юстиция. 2016. №3. С. 17-20.

2. Разогреева А. М., Миньков М. М. Условное осуждение и ограничение свободы: контроль и (или) ресоализация // Уголовное право. 2010. №4. С. 47-51.

3. Указ Президента Республики Узбекистан «О мерах по дальнейшему реформированию судебно-правовой системы, усилению гарантий надежной защиты прав и свобод граждан» 21.10.2016 УП-4850 http://lex.uz

4. Постановление Президента Республики Узбекистан «О мерах по кардинальному совершенствованию системы уголовного и уголовно-процессуального законодательства» 14.05.2018 ПП-3723 [http://lex.uz

5. Уголовный кодекс Республики Узбекистан. http://lex.uz

6. Статья 81 дополнена пунктом «а ${ }^{1} »$ Закона Республики Узбекистан от 29 марта 2017 года № 421. Собрание законов Республики Узбекистан. № 13. ст.194, 2017.

7. Закон Республики Узбекистан от 10 августа 2015 года «О внесении изменений и дополнений в некоторые законодательные акты Республики Узбекистан» // Собрание законодательства Республики Узбекистан. 2015. №32.

8. Попов В. В. Проблемы формирования и реализации уголовной и уголовноисполнительной политики в отношении несовершеннолетних. Вологда. 2012.

9. Уголовно-испольнительный Кодекс Республики Узбекистан http:/lex.uz

10. Информационно-правовой портал. https://www.norma.uz

11. Фейзуллаев Ф. М. Специальные меры предупреждения преступности несовершеннолетних в условиях пенитенциарного учреждения // Человек: преступление и наказание. 2015. №2(89). С. 130-134.

\section{Работа поступила}

в редакичию 14.02.2020 2.
Принята к публикациии 19.02.2020 2.

Ссылка для ичитирования:

Palvanov I. Criminal Responsibilities Adolescents and Features of Punishment System // Бюллетень науки и практики. 2020. Т. 6. №3. С. 357-362. https://doi.org/10.33619/2414$2948 / 52 / 46$

Cite as (APA):

Palvanov, I. (2020). Criminal Responsibilities Adolescents and Features of Punishment System. Bulletin of Science and Practice, 6(3), 357-362. https://doi.org/10.33619/2414-2948/52/46 